\title{
Enterprise Resource Planning Systems Implementation and Firm Performance: An Empirical Study
}

\author{
Irfan $\mathrm{Ali}^{1}$, W. J. H. van Groenendaal ${ }^{2}$, H. Weigand ${ }^{2}$
}

${ }^{1}$ Shah Abdul Latif University, Khairpur, PAKISTAN
${ }^{2}$ Tilburg University, Tilburg, THE NETHERLANDS
*Corresponding Author: w.j.h.vgroenendaal@uvt.nl

Citation: Ali, I., van Groenendaal, W. J. H., \& Weigand, H. (2020). Enterprise Resource Planning Systems Implementation and Firm Performance: An Empirical Study. Journal of Information Systems Engineering and Management, 5(1), em0109. https://doi.org/10.29333/jisem/7822

\section{ARTICLE INFO}

Published: 6 Mar. 2020

\begin{abstract}
Adopting an ERP system is a challenge for any firm and the problems associated with it initially often negatively affect the adopting firm's profitability as measured through a firm's main financial indicators. Also for a longer period of time after implementation the empirical results on adoption are mixed, although more positive results have been reported in recent years. However, over the many years of implementing ERP systems much knowledge has been gained on how to improve the implementation process and speeding up the realization of the benefits. This research investigates whether Pakistani manufacturing firms profited from this by realizing the financial benefits early on. This is empirically tested by comparing ten financial performance indicators of firms that adopted an ERP system to that of non-adopters between 2002 and 2012. The results show that they benefitted from the start, but not in all areas.
\end{abstract}

Keywords: Enterprise Resource Planning (ERP), financial performance, longitudinal study

\section{INTRODUCTION}

For many decades firms have been investing in information systems (IS) and information technology (IT) to improve their competitiveness. However, empirical research testing the productivity/profitability of IS/IT investments still show mixed results. Many notions to evaluate the business value of IS/IT investments have been used. Hitt and Brynjolfsson (1996), using a production function approach and firm level data, found a positive effect on productivity, but not on profitability. Mithas, Tafti, Bardhan, and Goh (2012), analyzing 400 global firms that invested in IT found a positive impact on revenue growth and net income per employee, and IT enabled revenue growth has a greater impact on profitability than IT-enabled cost reduction. Furthermore, IT expenditures have a greater effect on firm profitability than advertising and R\&D expenditures do. Banker, Bardhan, Chang, and Lin (2006), Liu and Lu (2011) reported a positive relationship between IS/IT investment and profitability also. Devaraj, Krajewski, and Wei (2007), Aral and Weill (2007), and Badescu and Garcés-Ayerbe (2009) on the other hand found a negative or no profitability gain following an IS/IT investment.

One problem when studying the effects of IS/IT technology investments might be IS/IT technology heterogeneity. Aral and Weill (2007) investigated the effects of IT/IS investments on market valuation, profitability, cost and innovation, and found that aggregate IT/IS investments provide no significant advantage for firms. Disaggregation of IT/IS investments is needed to analyze the effects. They distinguish infrastructural, transactional, informational, and strategic investments, each having a different effect on return on assets, net margin, cost of goods sold, and innovation. Infrastructure investments disrupt and are negatively associated with return on assets and net margin in the short run, but not in the long run. Transactional IT investments lower cost of goods sold. Informational investments on the other hand are positively correlated with return on assets and net margin, but not with cost of goods sold. Strategic investments have a positive effect on innovation. This shows that in order to analyze the effects of IT/IS investments different types of investments must be analyzed separately.

One of the most important IS technologies implemented by firms all over the world are Enterprise Resource Planning (ERP) systems. ERP systems are based on commonly used, often called best, practices and are constantly adapted to new developments. ERP vendors claim ERP systems have a wide range of advantages that result in cost reduction and improved profitability. However, implementing an ERP system is a complex process and for a successful implementation attention must be paid to many aspects (Behesthi \& Behesthi, 2010). Analyzing the effects of investing in ERP systems, which are both transactional and informational, is in line with Aral and Weill's (2007) requirement to disaggregate IT/IS investments. 
Research on ERP implementation often focusses on the implementation phase (Amid, Moalagh, \& Ravasan, 2012; Maguire, Ojiako, \& Said, 2010). ERP failure is defined as over time and over budget. However, this limits success to the implementation project and neglects the benefits after the project, which is at the core of this research.

Given the many aspects of a firm's activities affected by an ERP system, many different types of studies can be performed. Several studies emphasize the non-financial effects of investing in ERP, such as its role as an enabler of improved organizational capabilities (Kharuddin, Foong, \& Senik, 2015), labor productivity (Badescu \& Garcés-Ayerbe, 2009) or the effect of bundling it with an SCM-system (Wieder, Booth, Matolcsy, \& Ossimitz, 2006). Kocaaga, Ervural, Demirel, and Zaim (2019) analyze the effect on the performance of 9 critical success factors -ranging from the role of top management, compliance of the ERP system with business to data accuracy- in relation to both, ERP implementation and usage. They show a statistically significant positive relationship between ERP system performance and firm performance after, but not during implementation. The study of the impact of ERP implementation and usage on firms' operations is important to address the organizational problems of an implementation. However, it is the financial consequences after adoption that show whether it was a success.

Many studies, therefore, compare the effects of ERP adoption to non-adopters by analyzing well-known financial performance indicators, such as return on assets and equity, cost of goods sold and total asset turnover. Comparing adopters and non-adopters has the advantage that it corrects for those environmental circumstances that affect both in a similar way. When firms invest in ERP it depends on the market conditions whether it can capture the returns or has, due to competition, pass these on to customers (Dedrick, Gurbaxani, \& Kraemer, 2003). In the latter case it will only show up in the performance indicators when compared with those of non-adopters.

The focus in this research will be on financial performance at the firm level, more specifically, on profitability, cost reduction and efficiency, sales growth, and capital structure. Note that these four aspects are not independent of one another.

This study focusses on Pakistan, a developing country. The majority of the research on ERP implementation has been done in developed countries. With market saturation in the developed world, developing countries -especially in Asia and companies operating internationally- are a promising market for ERP implementations. This research wants to contribute to the discussion on the financial effects of ERP adoption by analyzing the introduction of ERP systems in Pakistan, a country that has fairly late jumped the ERP bandwagon. The advantage of this study is that matured ERP systems are introduced using implementation methods that have been developed over decades and applied in various cultures, resulting in a more level playing field.

Section 2 reviews the literature and formulates hypotheses. Section 3 addresses the data collection problem. Section 4 contains the empirical results for Pakistan, and Section 5 contains discussion and conclusions.

\section{LITERATURE REVIEW}

Since the focus of this study is on profitability, cost reduction and efficiency, sales growth, and capital structure effects of ERP investments on the firm level, the review will concentrate on the literature that analyses these effects.

\section{ERP and Profitability}

Investing in ERP promises sales growth and/or cost reduction, hence it is expected to increase the adopting firms' profitability compared to non-adopters. However, the empirical results of the impact of ERP implementation on firm performance are mixed. Hitt, Wu, and Zhou ${ }^{1}$ (2002) used regression analysis to compare adopters, and non-adopters and found that adopters perform better in terms of sales per employee, profit margins, return on assets (ROA) and accounts receivable turnover, but negative for return on equity (ROE). However, when analyzing adopting firms only, these had consistently better performance during than before or after implementation, with the exception of accounts receivable turnover, which improves both during and after adoption (Hitt et al., 2002). Hunton, Lippincott, and Reck (2003) compare the performance of pairs of ERP adopting and nonadopting firms ex-ante and ex-post over a three year period and found significantly better results in terms of ROA and return on invested capital (ROIC) for adopters compared to non-adopters; however, not for return on sales (ROS). Although they did not find any improvement in the absolute value of ROA and ROIC for adopters, adopters did better than non-adopters showing a competitive advantage for adopters by passing on the benefits to customers. This shows that when studying the impact of ERP on profitability, it pays off to include the financial performance of non-adopters to control for the firms' environmental effects, which are the same for adopters and non-adopters. Based on 213 firm observations Nicolaou \& Bajor (2004), using a t-test and Wilcoxon's $Z$ statistic, found no significant differences between adopters and non-adopters for the averages over the 3 years prior to adoption for ROA and ROS, but did for the averages over a 2 year post-implementation period for ROS, but not for ROA. Nicolaou (2004) matched annual data for the period 1990-1998 of adopters and non-adopters. ROA was significantly worse during and year one after adoption, but improved in years 2 and 4. ROS deteriorated during adoption and improved in years 3 and 4 .

The purpose of an ex-post analysis is to test the extent to which the implementing firm has been successful in realizing the expected benefits. Hendricks, Singhal, and Stratman (2007) analyzed, among others, the data of 186 US firms that implemented an ERP-system. They matched these to the median of an appropriate group of non-adopting competitors to determine the impact on the financial performance of adopters. Although not uniformly, ERP adopters show an improvement in ROA and some evidence of positive abnormal changes in ROS, but the latter result is not as strong as for ROA. Firms that invest in ERP do, however, not experience a statistically significant increase in stock returns. (Hendricks et al., 2007)

\footnotetext{
${ }^{1}$ The Annex contains an overview of all empirical studies on ERP adoption reviewed in terms of main objective, methodology, data used, and main findings.
} 
Kallunki, Laitinen, and Silvola (2011) used partial least squares to analyze 2007 survey data of 70 Finish business units. ERP adoption has a significant positive effect on financial and non-financial performance, which is strengthened by the use of formal controls. Kouki (2015) using GLS analyzed 106 French listed firms, 31 of which adopted ERP, 33 did not -but implemented nonfinancial performance indicators-, and 38 that implemented both. Kouki (2015) found a significant positive effect of ERP implementation as well as of non-financial performance indicators on ROA, which becomes much stronger when ERP usage is combined with the use of non-financial performance indicators. That combining ERP implementation with various managerial techniques has a significant positive effect on ROA and ROI is supported by the findings of Galy and Sauceda (2014), who linked survey data to actual financial data of 55 companies that implemented ERP between 1993 and 2001. Kharuddin et al. (2015) exploring the relationship between the extensiveness of the modules implemented and organizational performance found a significant positive effect on both, financial and non-financial performance. However, the latter becomes stronger with ERP extensiveness. This is supported by Parto, Sofian and Saat (2016) who found that implementing an ERP system wholly or partly has a positive effect on the ROA and ROI of Iranian manufacturing firms. Acar, Tarim, Zaim, Zaim, and Delene (2017), analyze the direct and indirect effects of ERP usage and the mediating effect of knowledge management on performance using the responses of 163 Turkish manufacturing firms. Their path analysis shows that, while ERP by itself does not, knowledge management has significant positive effects on operational performance especially when combined with ERP. This improvement in operational performance has a significant positive effect on financial performance in terms of profit, revenue and ROI. Zhang and Zheng (2019) on the other hand, using paired t-test to analyze before and after adoption results of 60 Chinese firms, found only a short term positive effect after implementation for ROS (2 years) and ROA (first year).

Not all empirical results are positive. Poston and Grabski (2001) compared the performance ratios before and after ERP implementation of 50 companies that adopted ERP packages from 1993 to 1997 and found no significant improvement in residual income. Velcu (2007) using the Mann-Whitney U test to compare 32 successful implementations with 17 less successful ones, found no significant improvement in ROA and ROI between the two groups. Liu, Miao, and Li (2008) investigated the impact of ERP implementation on pre-to-post financial performance of adopters compared to non-adopters for 50 Chinese chemical firms that implemented ERP between 1998 and 2005 and found no longer term positive or negative effects during implementation and three years after. However, the effect on ROA was significantly negative in the first year after implementation. De Andres, Lorca, and Labra (2012), analyzing 72 survey responses of Spanish firms that adopted an ERP system between 1989 and 2006, found that the ROA of adopters is significantly lower than that of non-adopters in the three years after adoption. Return on invested capital (ROIC) was not affected. However, sales grew in the first year after adoption. De Andres et al. (2012) believe the Spanish culture may require more time for firms to adjust before positive results emerge. In a recent study for India Gupta, Kumar, Singh, Foropon, and Chandra (2018) using survey data, empirically investigated the effect of cloud ERP services, but found no significant effect on average ROI, average profit and profit growth. However, they did find a positive effect on supply chain and market performance.

The analysis above shows that the results for ERP adoption are still mixed, but there is more evidence for positive effects than no or negative effects on ROE, ROA, ROS and ROIC. However, only a few studies show sustained positive effects, so further empirical evidence is needed. This leads to the first hypotheses:

H1a: ERP-adopting firms perform better than matching non-adopting firms do in terms of return on equity (ROE).

H1b: ERP-adopting firms perform better than matching non-adopting firms do in terms of return on assets (ROA).

H1C: ERP-adopting firms perform better than matching non-adopting firms do in terms of return on invested capital (ROIC).

H1d: ERP-adopting firms perform better than matching non-adopting firms do in terms of return on invested capital (ROS).

\section{ERP, and Cost Reduction and Efficiency}

Real-time information and automation are expected to help firms to reduce cost in numerous ways. See for example Kocaaga et al. (2019) for the many ways ERP supports most important critical success factors. ERP investments have evidenced efficiency effects through supporting lean operational and supply chain management processes. However, Poston and Grabski (2001) found no significant change in costs as a percentage of revenue until 3 years after the implementation of the ERP system, and then only for cost of goods sold as a percentage of sales (COGS). However, there was a significant decrease in the number of employees as a percentage of revenue all 3 years after ERP implementation. Also Nicolaou and Bajor (2004) showed a significant improvement of two year post implementation average of COGS. Nicoloau (2004) found a significant improvement only in the fourth year after adoption. Liu et al. (2008) on the other hand found a significant increase in COGS, but only for the first year after adoption.

Investing in ERP is expected to result in lower operating expenses to sales (OX) in the post implementation period. None of the studies reviewed actually tested the effect of ERP adoption on OX, which covers cost expenses for firms' day-to-day activities not directly associated with production. ERP adoption is expected to reduce operating expenses through, among others accuracy and automation, to gain competitive advantage and increase earnings. However, Poston and Grabski (2001) found no significant decreases associated with selling, general, and administrative costs scaled by revenues. This leads to the following hypotheses for costs:

H2a: ERP-adopting firms perform better than matching non-adopting firms do in terms of cost of goods sold to sales (COGS).

H2b: ERP-adopting firms perform better than matching non-adopting firms do in terms of operating expenses to sales (OX).

Deployment of ERP by firms is associated also with improved efficiency and inventory turnover, thus diminishing operational costs. Hitt et al.'s (2002) study shows significant improvements for total asset turnover (TAT) and inventory turnover (ITO). Hunton et al. (2003) found ERP adoption has a significant positive effect on TAT. Velcu (2007) found that successful implementations, when compared to less successful implementations, results in a significantly better TAT the first two years after adoption, although the ROA and ROI of successful implementations did not improve. ERP improves the time needed to fulfill customer orders, facilitating 
stock reduction thus enhancing ITO. ERP deployment injects efficiency through reducing coordination cost by ensuring tighter coordination among departments, although mostly in combination with more formal management control (Galy \& Sauceda, 2014; Kallunki et al., 2011; Kouki, 2015; Wieder et al., 2006). Zhang and Zheng (2019) also found a significant positive effect on ITO in the first two years after adoption. This leads to the following hypotheses for efficiency:

H3a: ERP-adopting firms perform better than matching non-adopting firms do in terms of total asset turnover (TAT).

H3b: ERP-adopting firms perform better than matching non-adopting firms do in terms of inventory turnover (ITO).

\section{ERP and Sales}

Through access to real-time data ERP is expected to improve efficiencies, including reduced cycle time, on time delivery, increased customer satisfaction and after sales services, and hence, increase sales. Velcu (2007) reports that ERP adopters make less mistakes in invoiced prices, which according to Kallunki et al. (2011) leads to sales growth (SG). The improved customer satisfaction will generate loyalty and willingness to pay, which finally leads to sales growth. The study by Kallunki et al. (2011) shows a positive effect of ERP adoption in combination with the use of formal controls on sales growth. De Andres et al. (2012) also found a positive effect on sales, but in the first year after adoption only. Galy and Sauceda (2014), analyzing ERP implementation in combination with applying managerial techniques, found a significant support for sales growth. With respect to ERP and sales growth the following hypothesis will be tested

H4: ERP-adopting firms perform better in terms of sales growth (SG) than non-adopting firms do.

\section{ERP Implementation Debt}

ERP implementation has been cited by many as a large and, if not managed properly, risky investment (Scott \& Vessey, 2002; Segars \& Chatterjee, 2010; Tian \& Xu, 2015). It can cost millions of dollars and lower financial performance that may impair the reputation of the firm in the market, so it can disturb the optimal capital structure of a firm. Not many studies pay attention to this aspect. A high debt equity ratio (DER) generally indicates that a company has been financing its growth with debt. According to the financing hierarchy of the Pecking Order Theory, profitable firms prefer the cheapest source of capital, first retained earnings, then debt, and if there is still need for capital firms issue equity (Myers \& Majluf, 1984). To avoid the risk of lower financial performance, firms need to depend less on debt during and shortly after implementation. Thus, it is expected that, when the investment is substantial enough, implementing ERP negatively affects an adopter's DER compared to that of non-adopting matching firms. Kouki (2015) includes DER in its analysis of ERP adoption, but it had no significant effect. When an implementation is risky Hitt et al. (2002) expect firms to utilize less debt financing before and during implementation. However, a successful implementation may allow firms to readjust their capital structure later on in the post ERP implementation period to get maximum tax benefits from an optimal capital structure.

H5: The debt-equity ratio (DER) of ERP-adopting firms declines as compared to that of the non-adopting matching firms.

\section{Concluding Remarks}

The results on the effect of ERP adoption are still mixed. Studies that compare before and after adoption performance data show, at least some, positive results. Nicolaou and Bajot (2004) show significant improvements for ROS and COGS, but not ROA and ITO. Hendricks et al. (2007), Kouki (2015), Zhang and Zheng (2019) show statistically significant improvement in ROA for at least one post-implementation period. Zhang and Zheng (2019) also found evidence for improvement of ROS. With respect to costs, Poston and Grabski (2001) found improvement only through a significant decrease in COGS in the third year after adoption. Zhang and Zheng (2019) results show a significant efficiency effect on ITO for two years after implementation. So the results of studies comparing before and after adoption performance data are positive, albeit limited.

Kallunki et al. (2011), Galy and Sauceda (2014), Kharuddin et al. (2015) and Acar et al. (2017) used questionnaires -sometimes in combination with actual financial firm data- to gather information on the effects of ERP implementation on financial and nonfinancial performance. These analyses show positive effects on -sometimes perceived, not actual- profitability and costs. Most studies concentrate more on the many managerial and operational aspects affected by ERP adoption. Several also look at the combination of ERP adoption and other initiatives, such as the use of formal control (Kallunki et al., 2011) or the effect of knowledge management (Acar et al., 2017).

When comparing adopters and non-adopters Hitt et al. (2002) and Hunton et al. (2003) found significant positive effects on several financial performance indicators for profitability and costs. The results of Nicoloau (2004) were absent or significantly negative at the start, but improved thereafter. Wieder et al. (2006) found performance differences only in combination with adopting a Supply Chain Management system. Two more recent studies, Liu et al. (2008) and de Andres et al. (2012) found short respectively longer-term negative effects on ROA. So studies comparing adopters and non-adopters show mixed results.

\section{DATA DEFINITION AND COLLECTION}

\section{Definition of Financial Indicators}

Table 1 contains an overview of the financial indicators used in the studies discussed above; for details also see the Annex. They are all related to the DuPont equation (Johnson, 1978), which is widely used for financial ratio analyses. Financial ratios of firms can be compared, which best suits the comparison of adopters and non-adopters used in this research. There is a clear link between the ratios and each one expresses information that can be used for comparison and evaluation. 
Table 1. Definition of financial indicators

\begin{tabular}{|c|c|}
\hline Variable & Definition \\
\hline \multirow[b]{2}{*}{$R O E$} & Operating Income \\
\hline & Return on Equity $=\frac{\text { Total Equity }}{\text { Tot }}$ \\
\hline \multirow{2}{*}{$R O A$} & Operating Income \\
\hline & Return on Assets $=\frac{\text { Total Assets }}{\text { Tot }}$ \\
\hline \multirow{2}{*}{ ROIC } & Return on Inpested Canital $=\quad$ Operating Income \\
\hline & Return on Investea captcal $=\overline{\text { Non current Liabilities }+ \text { Equity }}$ \\
\hline \multirow{2}{*}{ ROS } & Return on Sales $=$ Operating Income \\
\hline & Return on sales $=\frac{\text { Sales }}{2}$ \\
\hline \multirow{2}{*}{ COGS } & Costs of Goods Sold to Sales $=$ Costs of Goods Sold \\
\hline & Sales \\
\hline \multirow{2}{*}{$O X$} & Operating Expense to Sales $=$ Sales - Costs of Goods Sold - Operating Income \\
\hline & Sales \\
\hline TAT & Total Assets Turnover $=\frac{\text { Sales }}{\text { Tr }}$ \\
\hline \multirow[b]{2}{*}{ ITO } & $\begin{array}{c}\text { Total Assets } \\
\text { Costs of Goods Sold }\end{array}$ \\
\hline & Inventory Turnover $=\frac{\text { Inventory }}{\text { Indu }}$ \\
\hline SG & Sales Growth $=\frac{\text { Sales }_{t}-\text { Sales }_{t-1}}{\text { Sales }_{t-1}}$ \\
\hline \multirow{2}{*}{$D E R$} & Debt EauityRatio $=\frac{\text { Total Liabilities }}{}$ \\
\hline & 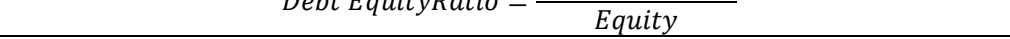 \\
\hline
\end{tabular}

- ROE shows how effectively a firm's management uses investors' money. It is a measure of profitability of shareholders' investments.

- ROA reveals how much profit a company earns on its assets. ROA can be used to compare firms in the same industry and can show the efficiency of a firm in using its assets to generate earnings. A higher ROA indicates that a firm is earning more with less. Together ROE and ROA provide a clear picture of management's effectiveness. If ROA is sound and debt levels are reasonable, a strong ROE is a solid signal for generating returns from shareholders' investments. However, if a firm is carrying a lot of debt, a high ROE can give a false impression about the firm's prosperity.

- ROIC shows how efficient a firm was in profitably investing capital. ROIC can be used to compare firms with different capital structures.

- ROS is a ratio used to evaluate a firm's operational efficiency. The percentage of total revenue that is converted into operating profits is a good measure for this. ROS can be used to compare competing firms, regardless of scale. However, depending on industry ROS varies, so comparisons should only be made within the same line of business.

- COGS is the cost of producing products over sales. The lower COGS, the better a firm is performing, it is a good indicator for the efficiency of doing business. COGS can be compared against other companies independent of the industry.

- OX is a measure of how efficient a company is and can be used to compare managerial flexibility and competency between firms within the same industry.

- TAT shows how a firm is performing in terms of revenue over assets. The higher TAT, the more productive and efficient a firm is. However, TAT tends to be higher in sectors with a relatively small asset base, such as retail. This makes it less useful for comparison over different sectors.

- ITO measures how fast a company is selling its inventory. The speed at which a company can sell inventory is a critical measure of business performance. Low ITO means weak sales, but a high ITO might indicate insufficient inventory.

- SG indicates whether adopters are doing better than non-adopters on the market. Since ERP is expected to increase managerial and operational efficiency, as well as customer satisfaction and employee productivity, it is expected to lead to sales growth also.

- DER, also referred to as leverage, measures the degree to which the assets of the firm are financed debts and equity. Lower values indicate less risk, since firms with higher values rely more on external lenders.

In what follows the effect of ERP adoption on these ten financial ratios will be empirically tested. The advantage is that it will give a more complete picture of all the financial implications of ERP adoption by listed firms in Pakistan.

Apart from possible positive effects of implementing ERP, there are many other factors that affect to the success of a firm. Controlling for all variables is difficult. This can be avoided by comparing the results of ERP adopting firms with those of matching non-adopters during the same time period. Without a matching control group on prior performance, it is unclear whether the observed effects are due to the event under consideration. Therefore, following prior research (Anderson et al., 2011; Balakrishnan, Linsmeier, \& Venkatachalam, 1996; Barber \& Lyon, 1996; Bharadwaj, 2000; de Andres et al., 2012; Etezady, 2008; Hunton et al., 2003; Lunardi et al., 2014; Nicolaou, 2004; Poston \& Grabseky, 2001) a matching sample of firms that have not implemented ERP will be used to estimate the effects of adopting ERP. Because all adopting and non-adopting firms operate in the same environment, the matching sample of non-adopters controls for factors other than ERP; such as, industry and the state of the economy.

Data were collected through a combination of methods, including a survey and collecting audited financial statements of the firms sampled. The companies surveyed are all joint stock companies at the Pakistan Stock Exchange. The sample consists of non- 
Table 2. Matching adopters and non-adopters

\begin{tabular}{|c|c|c|c|c|}
\hline \multirow[t]{2}{*}{ Sector } & \multirow{2}{*}{$\begin{array}{l}\text { Number of } \\
\text { firms }\end{array}$} & $\begin{array}{l}\% \text { of matched non-adopters } \\
\text { with ROA close to adopters }\end{array}$ & \multirow{2}{*}{$\begin{array}{l}\% \text { of matched non- } \\
\text { adopters in same } \\
\text { industry }\end{array}$} & \multirow{2}{*}{$\begin{array}{c}\% \text { of matched non-adopters } \\
\text { with size close to adopters } \\
75-125 \% \\
\end{array}$} \\
\hline & & $75-125 \%$ & & \\
\hline Chemicals & 18 & $81 \%$ & $44 \%$ & $75 \%$ \\
\hline Textile & 14 & $92 \%$ & $100 \%$ & $69 \%$ \\
\hline Engineering & 11 & $83 \%$ & $67 \%$ & $75 \%$ \\
\hline Fuel and energy & 9 & $100 \%$ & $50 \%$ & $50 \%$ \\
\hline Cement & 7 & $67 \%$ & $50 \%$ & $83 \%$ \\
\hline Sugar & 4 & $100 \%$ & $75 \%$ & $100 \%$ \\
\hline Paper and board & 4 & $100 \%$ & $50 \%$ & $75 \%$ \\
\hline Transportation and Communication & 3 & $50 \%$ & $50 \%$ & $75 \%$ \\
\hline Tobacco & 2 & $100 \%$ & $0 \%$ & $0 \%$ \\
\hline Jute & 1 & $0 \%$ & $100 \%$ & $100 \%$ \\
\hline Miscellaneous & 13 & $90 \%$ & $70 \%$ & $40 \%$ \\
\hline
\end{tabular}

financial firms registered at the Pakistan Stock Exchange, which is the largest and most liquid exchange of Pakistan, and publishes the financial data of the firms.

The survey aimed at gathering primary data on whether or not a firm had implemented ERP, in which year, etc. The response to the survey, send by email, was not satisfactory, so those who did not respond were approached by phone. The response rate increased considerably, but the amount of information was still considered insufficient. Therefore the audited financial statements of the sample firms were collected and analyzed. For these firms also the balance sheets as published by the State Bank of Pakistan were analyzed. This resulted in a combination of qualitative and quantitative data. Qualitative data such as ERP vendor, time of implementation, completion period, etc., and quantitative data covering the financial data. Combining the different sources 86 firms were identified that had adopted ERP between 2002 and 2012.

\section{Matching Adopters and Non-adopters}

Madapusi and D'Souza (2012), and de Andres et al. (2012) selected matching non-adopters based on size and industry. Anderson et al. (2011) used size to match non-adopters and ERP adopter. Barber and Lyon (1996) state that matching based on prior accounting metrics performance is critical to get powerful test statistics. Hendricks et al. (2007) argue that without matching prior performance it will be unclear to conclude whether the observed differences in performance is due to the event under consideration. Following Barber and Lyon (1996) and Hendricks et al. (2007) in combination with the arguments above, the nonadopting firms were, as much as possible, selected based on ROA, industry and size one year before the adoption of the ERP system. For this several steps were followed.

Step 1. For each sampled ERP adopter, all the non-adopters in the same industry of similar size were selected using State Bank of Pakistan's industry classification. For each adopter a firm was selected from all identified non-adopters whose ROA is within the range of 75-125 percent in the year preceding the ERP implementation year.

Step 2. If in Step 1 there is no firm in the same industry, then a firm within the range of 75-125 percent of ROA and with approximately the same size, but not within the same industry was selected.

Step 3. If Step 2 did not result in a match, a non-adopter with the closest ROA was selected without considering size or industry.

Table 2 indicates the extent to which matching adopters and non-adopters has been successful. Column 1 shows the sector and Column 2 the number of firms per sector. Column 3 shows the match between adopters and non-adopters based on ROA. For example, for Sugar there is a 100\% match in terms of ROA for all firms. Column 3 shows that only $75 \%$ ( 3 firms) of the match is within the same industry and Column 4 that all are within the $75-125 \%$ size range.

As Table 2 shows, the industry matching between ERP-adopters and non-adopters is limited. An important reason for this limitation is that in some sectors, for example Chemicals, many companies implemented an ERP system within a short time period, making it difficult to find appropriate matches. This industry mismatch between adopters and non-adopters may question the estimation results. To tackle this issue Melville, Kraemer, and Gurbaxani (2004) is followed and an industry dummy will be used to check if there was an industry effect.

Size has been given least priority while matching ERP adopters with non-adopters. As Table 2 shows here too it was sometimes difficult to find appropriate matches. Mabert, Soni, and Venkataramanan (2003) examined the impact of size on the financial performance of ERP adopters and found that larger firms have improvement in financial measures, whereas smaller firms performed better in manufacturing and logistics. To solve this critical issue, size will be used in the empirical part to test and control for the effect of differences in size.

\section{Period of Analysis}

To analyze the impact of ERP adoption on firm performance, the performance of adopters and non-adopter has been compared for one year before implementation, during implementation and for one year, two years and three years after implementation.

The data about ERP implementations in Pakistan has been collected among others directly from the audited financial statements of the firms. However, information about the implementation time is missing for the majority of the firms. Reviewing the literature on estimates of the implementation period, O'Leary (2000) reports that ERP implementation takes 1 to 3 years with 
Table 3. Data availability per variable per year

\begin{tabular}{|c|c|c|c|c|c|c|c|c|c|c|}
\hline \multirow{2}{*}{ Variable } & \multicolumn{5}{|c|}{ ERP Adopters } & \multicolumn{5}{|c|}{ ERP Non-adopters } \\
\hline & $t_{0}-1$ & $t_{0}$ & $t_{1}$ & $t_{2}$ & $t_{3}$ & $t_{0}-1$ & $t_{0}$ & $t_{1}$ & $t_{2}$ & $t_{3}$ \\
\hline$R O E$ & 73 & 73 & 70 & 66 & 53 & 67 & 67 & 65 & 61 & 48 \\
\hline$R O A$ & 63 & 63 & 61 & 58 & 46 & 67 & 67 & 64 & 60 & 48 \\
\hline ROIC & 74 & 74 & 71 & 67 & 54 & 69 & 69 & 67 & 63 & 50 \\
\hline ROS & 68 & 68 & 65 & 62 & 49 & 66 & 66 & 65 & 61 & 46 \\
\hline COGS & 68 & 68 & 67 & 62 & 51 & 69 & 69 & 66 & 61 & 48 \\
\hline$O X$ & 68 & 68 & 65 & 62 & 49 & 69 & 69 & 66 & 62 & 47 \\
\hline$T A T$ & 71 & 71 & 68 & 64 & 51 & 70 & 70 & 67 & 63 & 49 \\
\hline ITO & 55 & 55 & 52 & 49 & 37 & 56 & 56 & 52 & 48 & 34 \\
\hline$S G$ & 55 & 55 & 49 & 47 & 36 & 55 & 55 & 48 & 46 & 34 \\
\hline$D E R$ & 71 & 71 & 68 & 65 & 52 & 65 & 65 & 61 & 54 & 45 \\
\hline SIZE & 71 & 71 & 70 & 65 & 53 & 70 & 70 & 69 & 64 & 51 \\
\hline
\end{tabular}

an average of 21 months. Based on a study of 43 responding firms Stratman (2001) reports a 17.1 months average between the start of the implementation and go live. Mabert, Soni, and Venkataramanan (2000) conducted a survey among 479 manufacturing firms and report that it takes US manufacturing firms on average 17.5 months to complete an ERP implementation. More recently Nicolaou (2004) calculated a mean time period of 7.78 months based on actual times reported by firms. Etezady (2008) reports an average of 9.68 months. Both of these recent studies use one year as implementation period. Apparently learning from ERP implementations elsewhere has decreased the time needed to implement an ERP system, so a one year ERP implementation period seems appropriate.

With respect to choosing the appropriate implementation period one additional problem has to be solved. The moment in time an ERP-adopter goes life is different for each adopter and this will affect the results. A firm that deployed its ERP system in the first quarter uses it for about 9 months, but a firm that finishes implementation in the third or last quarter of the financial year deploys it considerably less. Furthermore, there is a difference in the financial reporting period of sampled firms, some firms' financial year ends on the 30th of June, whereas other firms report on the 31st of December. This implies that two adopters completing their ERP implementation in the same month could have a very different period of ERP deployment. To address this problem one year extra is added, so a two year average of the performance data for the year the ERP system was implemented and went life is used to indicate the effect of an ERP implementation. As a result the implementation period used covers (part of) the learning period also.

As far as the question of the time period required to capture the full impact of ERP implementation on firm performance is concerned, the existing literature provides little guidance about the length of post-implementation period (Hendricks et al., 2007). However, there is unanimous agreement to take several years. Hunton et al. (2003), Hendricks et al. (2007), Etezady, (2008), Mithas et al. (2012) and de Andrés, Lorca, and Labra (2012) used three to five years for measuring the impact of ERP adoption on firm performance. Hunton et al. (2003) and Etezady (2008) used an average of performance over a three year period prior to implementation as well as a three year period after implementation. De Andrés, Lorca, and Labra (2012) compare respectively, one, two and three years after implementation to pre-implementation values. Following these studies, a post-implementation period of 3 years is used. Given the incomplete match between adopters and non-adopters according to the criteria used in the literature the data were further cleaned by excluding outliers. Data were excluded if either Mahalanobis' distance or Cook's distance, that estimate the influence of a data point when performing a least-squares, indicated an outlier. Note that for all firms not all the data on each variable are available for each year. To utilize all data, the post-implementation years are flexible. If data are available for only one or two years these were included in the sample. Table 3 gives an overview of the samples available for each variable for $t_{0}-1$, the year before implementation started, $t_{0}$ the two year implementation period, and $t_{1}, t_{2}, t_{3} t$ the three years thereafter.

\section{EMPIRICAL FINDINGS}

Regression analysis is used to analyze the effect of ERP adoption for all variables in Table 1. The general form of the equation is

$$
A_{t}=\beta_{0}+\beta_{1} A_{t_{0}-1}+\beta_{2} S I Z E_{t}+\beta_{3} D_{E R P}+\beta_{4} D_{I n d u}
$$

with $A \in\{R O E, R O A, R O I C, R O S, C O G S, O X T A T, I T O, S G, D E R\}$ the financial ratios and $t \in\left\{t_{0}, t_{1}, t_{2}, t_{3}\right\}$ the time periods considered. So the effect for each period is compared separately to that in the year before the ERP-system was adopted. Performance in $t_{0}-1$ is regressed on performance in $t_{0}, t_{1}, t_{2}$ and $t_{3}$ to compare the implementation and post-implementation impact of ERP adoption on the different financial performance indicators. Remember, $A_{t_{0}}$ shows the average performance during the two year implementation period, an effect that has often been ignored by previous studies (Hunton et al., 2003).

- $\beta_{1}$ is the effect of pre-ERP adoption performance as measured by performance in $t_{0}-1$. It links the financial performance ratios for all firms -adopters and non-adopters- to their historic value as measured in the year before competitors started to adopt. 
Table 4. Estimates for the industry dummies

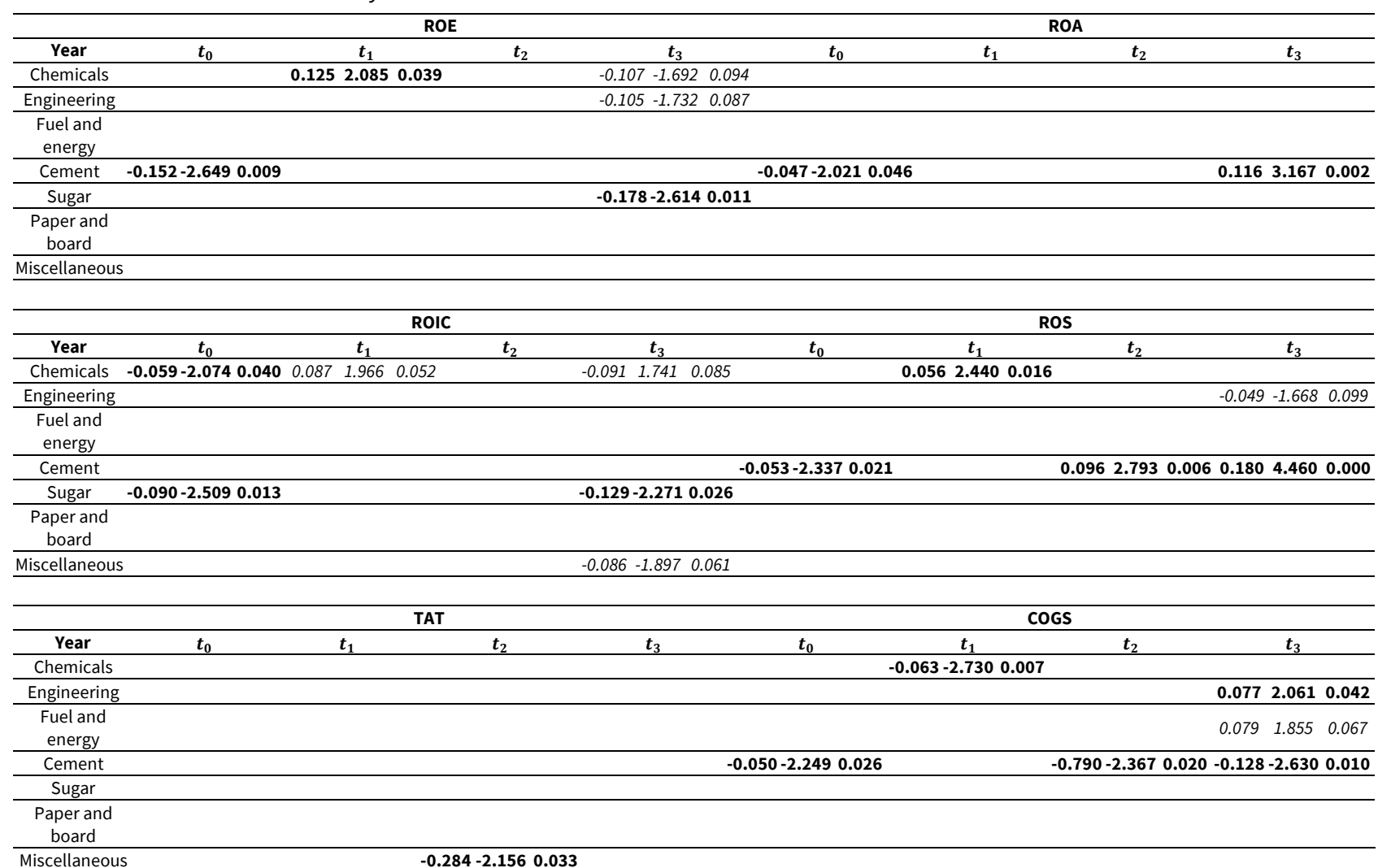

Legend: Bold means significant at the $5 \%$ level and italics at the $10 \%$ level

- $\quad \beta_{2}$ measures the effect of size (SIZE). As stated above, the objective is to control for the effect of size because the match for size between ERP adopters and non-adopters does not meet the strictest criteria; see Section 3.

- $\beta_{3}$ measures the effect of adopting ERP. $D_{E R P}$ is equal to 1 for ERP-adopters and 0 for non-adopters. A positive or negative value for $\beta_{3}$ in either of the periods $t_{0}, t_{1}, t_{2}, t_{3}$ implies that in that particular period the adopting firms perform different than their non-adopting competitors do on the particular financial ratio.

- $\quad \beta_{4}$ measurers the effect of the industry dummy, which was introduced to control for the fact that sufficient matching adopters and non-adopters were not available within a particular industry.

The suitability of the multiple regression model has been examined using SPSS. The assumption of normality of the data assumption was reviewed through skewness and kurtosis, which reveal no violation of this assumption. Furthermore, Pearson's correlation matrix among independent variables indicated no multicollinearity problem. The normal p-p plots show the residuals cluster around the line for all variables, suggesting the assumption of normality has been met.

The estimation results using pooled data for the impact of ERP adoption for the periods $t_{0}, t_{1}, t_{2}, t_{3}$ are in Tables 5-8 respectively. The results for the industry dummies, introduced to account for adopters and non-adopters not being from the same industry, are in Table 4.

\section{Estimation Results for Industry and Size Mismatches in Data Collection}

Table 4 shows that the estimates for several dummies are significant, but only for the sector Cement - $50 \%$ match in Table 2and to a lesser extend Chemicals $-44 \%$ match in Table 2-, the results are significant for several variables and several periods. For Cement ROE, ROA, ROS and COGS the estimates $\hat{\beta}_{4}$ are significant. During implementation the effects are negative -0.152 ( $p$-value 0.009), -0.047 ( $p$-value 0.046), -0.053 ( $p$-value 0.021 ) and -0.050 ( $p$-value 0.026 ) respectively. For ROE, ROA, and ROS this means adopters are performing less than non-adopters and accounts for the fact that for this sector the match between these two was not perfect. The negative effect for COGS implies that adopters are doing better in terms of cost. For ROA, ROS and COGS there are also statistically significant results in the post implementation period, but not for $t_{1}$. Note that the effects are increasing, indicating that the differences between adopters and non-adopters are becoming larger in size. For ROS and COGS the industry effect in $t_{2}$ is 0.096 ( $p$-value 0.006 ) and -0.790 ( $p$-value 0.020 ) respectively. The effects for ROA, ROS and COGS in $t_{3}$ are 0.116 ( $p$-value 0.002 ), 0.180 ( $p$-value 0.000 ) and -0.128 ( $p$-value 0.010) respectively; see Table 4.

For Chemicals the estimates $\hat{\beta}_{4}$ are significant for several periods for ROE, ROIC, ROS and COGS. For ROIC $\hat{\beta}_{4}$ is significant during implementation; -0.059 ( $p$-value 0.040). For ROE (0.125, p-value 0.039), ROIC (0.087, p-value 0.052), ROS (0.056, p-value $0.016)$ and COGS $(-0.063$, $p$-value 0.007$) \hat{\beta}_{4}$ is significant in $t_{1}$. For ROE the industry effect in $t_{3}$ is -0.107 ( $p$-value 0.094$)$ and for ROIC 0.091 (p-value 0.085 ), so only significant at the $10 \%$ level. 
Table 5. Estimates of improvement during implementation

\begin{tabular}{|c|c|c|c|c|c|c|c|c|c|c|c|c|c|}
\hline \multirow{2}{*}{ Variable } & \multicolumn{3}{|c|}{ Intercept } & \multicolumn{3}{|c|}{ Pre-adoption value } & \multicolumn{3}{|c|}{ SIZE } & \multicolumn{3}{|c|}{ ERP adoption effect } & \multirow{2}{*}{$R_{a d j}^{2}$} \\
\hline & $\widehat{\boldsymbol{\beta}}_{0}$ & $t$ & p-value & $\widehat{\beta}_{1}$ & $t$ & p-value & $\widehat{\boldsymbol{\beta}}_{2}$ & $t$ & p-value & $\widehat{\boldsymbol{\beta}}_{3}$ & $t$ & p-value & \\
\hline$R O E$ & 0.019 & 0.284 & 0.777 & 0.394 & 6.558 & 0.000 & 0.014 & 1.615 & 0.109 & 0.080 & 2.927 & 0.004 & 0.357 \\
\hline$R O A$ & -0.006 & -0.178 & 0.859 & 0.616 & 10.11 & 0.000 & 0.004 & 1.121 & 0.264 & 0.034 & 3.179 & 0.002 & 0.512 \\
\hline ROIC & 0.053 & 1.102 & 0.273 & 0.537 & 10.759 & 0.000 & 0.002 & 0.389 & 0.698 & 0.054 & 2.891 & 0.005 & 0.543 \\
\hline ROS & -0.054 & -2.001 & 0.048 & 0.579 & 9.401 & 0.000 & 0.011 & 3.010 & 0.003 & 0.008 & 0.767 & 0.445 & 0.542 \\
\hline COGS & 0.217 & 3.841 & 0.000 & 0.752 & 14.763 & 0.000 & 0.001 & 0.419 & 0.676 & -0.021 & -2.019 & 0.046 & 0.725 \\
\hline$O X$ & 0.031 & 1.733 & 0.086 & 0.708 & 13.593 & 0.000 & -0.003 & -1.316 & 0.191 & 0.003 & 0.377 & 0.707 & 0.734 \\
\hline$T A T$ & 0.157 & 0.854 & 0.395 & 0.873 & 19.543 & 0.000 & -0.002 & -0.106 & 0.916 & 0.134 & 2.253 & 0.026 & 0.799 \\
\hline ITO & -0.176 & -0.086 & 0.932 & 0.493 & 8.088 & 0.000 & 0.395 & 1.557 & 0.123 & -0.259 & -0.357 & 0.722 & 0.518 \\
\hline$S G$ & -0.236 & -0.163 & 0.871 & -0.061 & -2.058 & 0.042 & 0.085 & 0.469 & 0.640 & 0.657 & 1.204 & 0.232 & 0.429 \\
\hline$D E R$ & -0.089 & -0.286 & 0.776 & 0.629 & 12.727 & 0.000 & 0.089 & 2.274 & 0.025 & -0.164 & -1.355 & 0.178 & 0.617 \\
\hline
\end{tabular}

Legend: Bold means significant at the $5 \%$ level and italics at the $10 \%$ level

Table 6. Estimates of improvement in the first year after implementation

\begin{tabular}{|c|c|c|c|c|c|c|c|c|c|c|c|c|c|}
\hline \multirow{2}{*}{ Variable } & \multicolumn{3}{|c|}{ Intercept } & \multicolumn{3}{|c|}{ Pre-adoption value } & \multicolumn{3}{|c|}{ SIZE } & \multicolumn{3}{|c|}{ ERP adoption effect } & \multirow{2}{*}{$R_{a d j}^{2}$} \\
\hline & $\widehat{\boldsymbol{\beta}}_{0}$ & $t$ & p-value & $\widehat{\beta}_{1}$ & $t$ & p-value & $\widehat{\boldsymbol{\beta}}_{2}$ & $t$ & p-value & $\widehat{\boldsymbol{\beta}}_{3}$ & $t$ & p-value & \\
\hline$R O E$ & -0.123 & -1.045 & 0.298 & 0.354 & 3.753 & 0.000 & 0.019 & 1.326 & 0.187 & 0.091 & 2.300 & 0.023 & 0.250 \\
\hline$R O A$ & 0.013 & 0.254 & 0.800 & 0.528 & 6.073 & 0.000 & 0.000 & 0.010 & 0.992 & 0.052 & 4.135 & 0.000 & 0.341 \\
\hline ROIC & -0.024 & -0.281 & 0.779 & 0.464 & 5.779 & 0.000 & 0.005 & 0.449 & 0.654 & 0.066 & 2.288 & 0.024 & 0.341 \\
\hline ROS & -0.037 & -0.790 & 0.431 & 0.420 & 4.555 & 0.000 & 0.006 & 1.029 & 0.306 & 0.020 & 1.273 & 0.206 & 0.271 \\
\hline COGS & 0.245 & 2.967 & 0.004 & 0.707 & 9.815 & 0.000 & 0.006 & 1.147 & 0.254 & -0.028 & -1.935 & 0.056 & 0.584 \\
\hline$O X$ & 0.060 & 1.802 & 0.074 & 0.770 & 9.061 & 0.000 & -0.005 & -1.241 & 0.217 & -0.009 & -0.840 & 0.403 & 0.511 \\
\hline TAT & 0.653 & 2.210 & 0.029 & 0.686 & 10.349 & 0.000 & -0.043 & -1.309 & 0.193 & 0.266 & 2.994 & 0.003 & 0.565 \\
\hline ITO & -0.550 & -0.193 & 0.847 & 0.547 & 6.346 & 0.000 & 0.446 & 1.313 & 0.193 & 0.067 & 0.084 & 0.933 & 0.398 \\
\hline$S G$ & -6.006 & -0.518 & 0.606 & 0.535 & 3.005 & 0.004 & 0.322 & 0.232 & 0.817 & 1.385 & 0.401 & 0.690 & 0.076 \\
\hline$D E R$ & 0.283 & 0.441 & 0.660 & 0.454 & 5.387 & 0.000 & 0.092 & 1.209 & 0.229 & -0.040 & -0.199 & 0.843 & 0.262 \\
\hline
\end{tabular}

Table 7. Estimates of improvement in the second year after implementation

\begin{tabular}{|c|c|c|c|c|c|c|c|c|c|c|c|c|c|}
\hline \multirow{2}{*}{ Variable } & \multicolumn{3}{|c|}{ Intercept } & \multicolumn{3}{|c|}{ Pre-adoption value } & \multicolumn{3}{|c|}{ SIZE } & \multicolumn{3}{|c|}{ ERP adoption effect } & \multirow{2}{*}{$R_{a d j}^{2}$} \\
\hline & $\widehat{\boldsymbol{\beta}}_{\mathbf{0}}$ & $t$ & p-value & $\widehat{\beta}_{1}$ & $t$ & $p$-value & $\widehat{\boldsymbol{\beta}}_{2}$ & $t$ & p-value & $\widehat{\boldsymbol{\beta}}_{3}$ & $T$ & $p$-value & \\
\hline$R O E$ & -0.047 & -0.414 & 0.679 & 0.338 & 3.869 & 0.000 & 0.012 & 0.828 & 0.410 & 0.140 & 3.544 & 0.001 & 0.236 \\
\hline$R O A$ & 0.019 & 0.378 & 0.706 & 0.532 & 5.788 & 0.000 & 0.000 & -0.085 & 0.933 & 0.059 & 3.846 & 0.000 & 0.304 \\
\hline ROIC & 0.096 & 1.174 & 0.243 & 0.387 & 5.176 & 0.000 & -0.006 & -0.614 & 0.541 & 0.105 & 3.687 & 0.000 & 0.281 \\
\hline ROS & -0.101 & -2.055 & 0.042 & 0.328 & 3.433 & 0.001 & 0.014 & 2.145 & 0.034 & 0.038 & 2.245 & 0.027 & 0.326 \\
\hline COGS & 0.243 & 2.709 & 0.008 & 0.713 & 9.186 & 0.000 & 0.007 & 1.173 & 0.243 & -0.051 & -3.225 & 0.002 & 0.548 \\
\hline$O X$ & 0.093 & 2.845 & 0.005 & 0.815 & 9.837 & 0.000 & -0.008 & -2.130 & 0.035 & -0.017 & -1.466 & 0.145 & 0.607 \\
\hline TAT & 0.668 & 2.311 & 0.023 & 0.733 & 11.097 & 0.000 & -0.044 & -1.359 & 0.177 & 0.290 & 3.138 & 0.002 & 0.605 \\
\hline ITO & 2.764 & 0.412 & 0.682 & 0.899 & 5.925 & 0.000 & 0.252 & 0.317 & 0.752 & -2.605 & -1.343 & 0.183 & 0.298 \\
\hline$S G$ & -1.402 & -0.167 & 0.868 & 0.011 & 0.074 & 0.942 & -0.017 & -0.017 & 0.987 & 0.858 & 0.323 & 0.748 & 0.275 \\
\hline$D E R$ & 0.767 & 1.075 & 0.285 & 0.353 & 3.731 & 0.000 & 0.094 & 1.106 & 0.271 & -0.183 & -0.807 & 0.421 & 0.213 \\
\hline
\end{tabular}

Table 8. Estimates of improvement in the third year after implementation

\begin{tabular}{|c|c|c|c|c|c|c|c|c|c|c|c|c|c|}
\hline \multirow{2}{*}{ Variable } & \multicolumn{3}{|c|}{ Intercept } & \multicolumn{3}{|c|}{ Pre-adoption value } & \multicolumn{3}{|c|}{ SIZE } & \multicolumn{3}{|c|}{ ERP adoption effect } & \multirow{2}{*}{$R_{a d j}^{2}$} \\
\hline & $\widehat{\boldsymbol{\beta}}_{0}$ & $t$ & p-value & $\widehat{\beta}_{1}$ & $t$ & p-value & $\widehat{\boldsymbol{\beta}}_{2}$ & $t$ & p-value & $\widehat{\boldsymbol{\beta}}_{3}$ & $T$ & p-value & \\
\hline$R O E$ & 0.049 & 0.446 & 0.657 & 0.173 & 1.784 & 0.078 & 0.012 & 0.919 & 0.361 & 0.178 & 4.689 & 0.000 & 0.315 \\
\hline$R O A$ & 0.042 & 0.837 & 0.405 & 0.383 & 3.746 & 0.000 & -0.005 & -0.770 & 0.444 & 0.069 & 4.239 & 0.000 & 0.287 \\
\hline ROIC & 0.094 & 1.035 & 0.304 & 0.282 & 3.220 & 0.002 & 0.000 & -0.043 & 0.966 & 0.133 & 4.242 & 0.000 & 0.258 \\
\hline ROS & 0.013 & 0.234 & 0.816 & 0.425 & 3.963 & 0.000 & 0.001 & 0.112 & 0.911 & 0.054 & 2.831 & 0.006 & 0.379 \\
\hline COGS & 0.354 & 2.809 & 0.006 & 0.600 & 5.418 & 0.000 & 0.000 & 0.003 & 0.997 & -0.056 & -2.412 & 0.018 & 0.413 \\
\hline$O X$ & 0.026 & 0.709 & 0.480 & 0.656 & 7.383 & 0.000 & -0.001 & -0.261 & 0.795 & -0.004 & -0.338 & 0.736 & 0.553 \\
\hline$T A T$ & 0.561 & 1.756 & 0.083 & 0.733 & 9.821 & 0.000 & -0.057 & -1.596 & 0.114 & 0.280 & 2.65 & 0.010 & 0.593 \\
\hline ITO & -12.11 & -1.295 & 0.201 & 0.106 & 0.630 & 0.531 & 2.448 & 2.231 & 0.030 & -0.536 & -0.211 & 0.833 & 0.015 \\
\hline$S G$ & -5.555 & -0.879 & 0.383 & 0.185 & 1.926 & 0.059 & 0.504 & 0.663 & 0.510 & 1.193 & 0.565 & 0.575 & 0.020 \\
\hline$D E R$ & 0.626 & 0.833 & 0.407 & 0.492 & 4.867 & 0.000 & 0.041 & 0.471 & 0.639 & -0.210 & -0.844 & 0.401 & 0.257 \\
\hline
\end{tabular}

There are significant results for Engineering, Fuel and energy, and Miscellaneous, but these are not systematic. However, all significant values imply that the correction for the data mismatch through the introduction of an industry dummy for these sectors was needed, especially for the sectors Cement and Chemicals for which the mismatch in terms of industry were the largest.

\section{Effect of Size}

SIZE has been included to control for the effect of differences in size on the financial performance of the firms when matching adopters and non-adopters. Tables 5 to 8 show that SIZE is only significant for ROS in $t_{2}$. This indicates that with respect to size our match of data for adopters and non-adopters is a good match. 
Table 9. Support for hypotheses

\begin{tabular}{|c|c|c|c|c|c|c|}
\hline \multirow{3}{*}{ Category } & \multirow{3}{*}{\multicolumn{2}{|c|}{ Hypotheses }} & \multicolumn{4}{|c|}{ Implementation } \\
\hline & & & \multirow{2}{*}{ During } & \multicolumn{3}{|c|}{ After } \\
\hline & & & & year 1 & year 2 & tear 3 \\
\hline \multirow{4}{*}{ Profitability } & $\mathrm{H} 1 \mathrm{a}$ & $\mathrm{ROE}$ & yes & yes & yes & yes \\
\hline & $\mathrm{H} 1 \mathrm{~b}$ & $\mathrm{ROA}$ & yes & yes & yes & yes \\
\hline & $\mathrm{H} 1 \mathrm{C}$ & ROIC & yes & yes & yes & yes \\
\hline & $\mathrm{H} 1 \mathrm{~d}$ & ROS & no & no & yes & yes \\
\hline \multirow{4}{*}{ Cost \& Efficiency } & $\mathrm{H} 2 \mathrm{a}$ & COGS & yes & yes & yes & yes \\
\hline & $\mathrm{H} 2 \mathrm{~b}$ & OX & no & no & no & no \\
\hline & $\mathrm{H} 3 \mathrm{a}$ & TAT & yes & yes & yes & yes \\
\hline & $\mathrm{H} 3 \mathrm{~b}$ & ITO & no & no & no & no \\
\hline Sales & $\mathrm{H} 4$ & SG & no & no & no & no \\
\hline Debt-Equity & $\mathrm{H} 5$ & DER & no & no & no & no \\
\hline
\end{tabular}

\section{Effect of Pre-adoption Values}

The estimates $\hat{\beta}_{1}$ are significant for ROE, ROA, ROIC, ROS, TAT and COGS for all periods; see Tables 5 to 8 . A firm's results builds on previous results and $\hat{\beta}_{1}$ indicates to what extend the financial ratios build on the pre-adoption values during and after implementation. One expects this effect to decrease with time. Tables 5 to 8 show that the effect of the pre-adoption decreases from from 0.616 ( $p$-value 0.000 ) to 0.383 ( $p$-value 0.000 ) for ROA and for ROIC from 0.537 ( $p$-value 0.000 ) to 0.282 ( $p$-value 0.002 ). For ROE $\hat{\beta}_{1}$ also decreases, from 0.394 (p-value 0.000 ) in $t_{0}$ to 0.338 (p-value 0.000 ) in $t_{2}$ and is in significant in $t_{3}(0.173$, p-value 0.078). For ROS $\hat{\beta}_{1}$ decreases for $t_{0}, t_{1}, t_{2}$, but it increases in $t_{3}$; see Tables 5-8. Note however that $\hat{\beta}_{3}$ for ROS during implementation and the first year after adaptation is not significant. For TAT the estimate for the effect of pre-adoption first decreases from 0.873 ( $\mathrm{p}$-value 0.000 ) in $t_{0}$ to 0.686 ( $\mathrm{p}$-value 0.000 ) in $t_{1}$, and then increases to 0.733 ( $\mathrm{p}$-value 0.000 ) in $t_{2}$ and $t_{3}$. The decrease for COGS is much less, from 0.752 ( $p$-value 0.000 ) in $t_{0}$ to 0.600 ( $\mathrm{p}$-value 0.078 ) in $t_{3}$.

For OX, ITO, SG and DER $\hat{\beta}_{1}$ is significant two or more periods, but the effect of ERP adoption is not. What this might imply is discussed in Section 5.

\section{Estimation Results for ERP Adoption}

Tables 5 to 8 show support for six of the 10 hypotheses of Section 3. In general the results show that ERP-adopters perform significantly better than non-adopters in the post implementation period, but surprisingly also during implementation.

\section{Effects of ERP adoption during implementation}

The effects of ERP adoption for the average of the financial variables for the two year adoption period is discussed first; see Table 5. Surprisingly, the effect of implementing and going life does not have any significant negative financial effects for adopters. For ROE, ROA and ROIC there are small-0.080 ( $p$-value 0.004), 0.034 ( $p$-value 0.002), 0.054 ( $p$-value 0.005 ) respectively-, but significant positive effects, which is surprising and contrary to the general believe that firms will perform worse when implementing ERP. This might indicate that firms in Pakistan profit from the implementation experience and methods from other countries, since firms in Pakistan are relatively late in adopting ERP. For ROS $\hat{\beta}_{3}$ is not statistically significant $(0.008 p$-value 0.445$)$. The TAT of ERP-adopters improves considerably by $\hat{\beta}_{3}=0.134$ ( $p$-value 0.026 ). Also the cost of goods sold (COGS) already go down slightly on average $(-0.02$, p-value 0.046$)$ during the two year implementation and learning period. The estimates for OX, ITO, SG and DER are not significant. These results imply that for the implementation period hypotheses $\mathrm{H} 1 \mathrm{a}, \mathrm{H} 1 \mathrm{~b}, \mathrm{H} 1 \mathrm{c}, \mathrm{H} 2 \mathrm{a}$ and $\mathrm{H} 3 \mathrm{a}$ are supported, while H1d, H2b, H3b, H4 and H5 are not; also see Table 9.

\section{Effects of adoption after implementation}

The results of the regression analysis clearly support hypothesis $\mathrm{H} 1$ that ERP-adopting firms perform better than non-adopting firms do in terms of ROE, ROA, ROIC. In the first year after implementation the positive effect of adoption on ROE, ROA, ROIC continuous, whereas the effect on ROS is still statistically insignificant; see Table 6 . Tables 7 and 8 show that the effects are not wearing off, but are increasing. For ROE from 0.080 ( $p$-value 0.0004 ) during implementation, via 0.091 ( $p$-value 0.023 ) in $t_{1}, 0.140$ ( $\mathrm{p}$-value 0.001 ) in $t_{2}$ to 0.178 ( $\mathrm{p}$-value 0.000$)$ in $t_{3}$. ROA and ROIC show a similar pattern, increasing from 0.034 ( $\mathrm{p}$-value 0.002 ) to 0.069 ( $p$-value 0.000 ) and 0.054 ( $p$-value 0.002 ) to 0.133 ( $p$-value 0.000 ) respectively. For ROS the effect of adopting ERP becomes significant in $t_{2}$. Here too the size of the effect is increasing, from 0.038 ( $\mathrm{p}$-value 0.027 ) in $t_{2}$ to 0.054 ( $\mathrm{p}$-value 0.006 ) in $t_{3}$. These results clearly confirm hypotheses $\mathrm{H} 1$ and show that ERP-adopting firms perform better than non-adopting firms do in terms of return on equity $(\mathrm{ROE})$, return on assets $(\mathrm{ROA})$, return on invested capital (ROIC), and, albeit to a lesser extent, return on sales (ROS).

The estimation results confirm that ERP can lead to a significant reduction in COGS. The effect of ERP adoption on COGS is increasing in magnitude from -0.028 ( $\mathrm{p}$-value 0.056 ) in $t_{1},-0.051$ ( $\mathrm{p}$-value 0.002 ) in $t_{2}$, to -0.056 ( $\mathrm{p}$-value 0.018 ) in $t_{3}$. This clearly indicates that the cost of goods sold as a fraction of sales (COGS) of adopters becomes significantly lower than that of nonadopters with the passage of time; supporting hypothesis H2a. For OX none of the values is statistically significant, so $\mathrm{H} 2 \mathrm{~b}$ is rejected.

For TAT the results are clear and the effect more than doubles in $t_{1}$ to 0.266 ( $p$-value 0.010 ) compared to $t_{0}$ and stays that high approximately in the next two years. The results for ITO are not significant for any period, so H3a is supported, but $\mathrm{H} 3 \mathrm{~b}$ is not. 
Hypothesis H4, ERP-adopting firms perform better in terms sales, is not supported by the empirical findings for any time period; see Tables 6-8, as is H5, which asserts a reduction in DER of adopters compared to the control group shows no significant effects. This may be because the financial burden of ERP implementation is too limited to affect DER significantly. Table 9 contains an overview of the results.

\section{Robustness of Results}

Are these results robust? The financial data have been carefully collected directly from audited financial statements of the firms. Outliers have been removed by applying Mahalanobis Distance and Cooks Distance tests, and the use of size and industry dummies assures that possible mismatches between adopters and non-adopters are taken into account as much as possible. Furthermore, the normality of data has been checked through Skewness and Kurtosis Z-values, which indicated the normality of data distribution in this study. This is sufficient to guarantee robustness.

\section{DISCUSSION AND CONCLUSIONS}

The effect of ERP adoption on ten possible indicators, all related to the DuPont equation and more than most previous studies did, were empirically tested. The results show that investing in ERP in Pakistan has had a positive effect on the most important financial performance indicators when comparing adopters and non-adopters. This effect already occurs during the two year implementation period, which also covers (part of) the startup learning period. The significant positive results for ROE, ROA, ROIC, COGS and TAT of adopters during implementation are remarkable and contrary to the general believe that ERP projects disrupt business.

Surprisingly adopting firms do not perform better in terms of sales growth (SG) than non-adopting firms do. This is contrary to the findings by Kallunki et al. (2011), Galy and Sauceda (2012) and Acar et al. (2017), who found a positive relationship between ERP implementation and sales growth. This finding implies that the improvement of ROE and ROA of adopters compared to nonadopters can only be caused by two other effects, a better use of assets and/or relatively larger net profits due to lower costs. The improvement of ROE means that adopters generate more returns for shareholders. This can be concluded since our results show that DER is not affected by adopting ERP, so the increase is not the result of a change in debt level. The improvement of ROA shows that adopting firms make more effective use of their asset base. As the Annex shows, many empirical studies show a positive effect on ROA too. However, of the studies comparing adopters and non-adopters, which in our view is the best way to analyze adoption effects, Hitt et al. (2002), Hunton et al. (2003) and Nicolaou (2004) found positive effects, whereas Wieder et al. (2006), Liu et al. (2008) and de Andres et al. (2012) found none or a negative effect on ROA.

ROIC is especially useful for capital intensive industries and can be used to compare firms with different capital structures. The significantly higher ROIC implies that adopters are using their machinery, etc. better than non-adopters do. So adopting firms are becoming more competitive.

With TAT of adopters improving for all periods compared to non-adopters and with no significant effect of adoption on sales, this can only mean that ERP adopters use their assets more efficient than non-adopters do, confirming the efficiency claim of ERP implementation. This is supported by the improvement of ROS, an indicator for operational efficiency, which is significant only after year one, so it takes some time before the efficiency is measurable in operating income.

Costs of goods sold are those that are directly tied to the production of the products or services, such as the cost of labor, materials, and manufacturing overhead. Therefore, a lower COGS shows better use of resources, especially since it is improving compared to non-adopters independent of the state the Pakistani economy is in. A lower COGS also means a higher net profit and thus an improvement in ROS. Together the significant increases in TAT and ROS are responsible for the increase in ROE and ROA. The significant effects on ROA and COGS show that ERP adoption support transactional (COGS) as well as informational (ROA) improvements, two of Aral and Weill's (2007) four advantages of IT/IS investments.

Surprisingly the results for ITO and OX are not significant for any of the four periods. For ITO this may be because with the decrease in cost of goods sold and a more efficient operational management due to the implementation of ERP also inventory levels go down, so the decrease in the ratio of the two may be statistically insignificant. Operating costs are recurring cost that are not directly related to actual goods or services. The effect of adopting ERP on the efficiency of managing these cost is not significant, which is in line with the findings of Poston and Grabski (2001).

Most of the industries included in our sample are manufacturing companies that require substantial investments. Although investing in ERP requires a substantial investment, it is still relatively small for large capital intensive sectors like Chemicals, Cement, and Paper and Board. For these sectors the effect of investing in ERP does not affect the firms' liabilities, nor equity, to such an extent that it has a significant effect on its debt equity ratio.

This study empirically confirms adoption does improve a firm's competitiveness since adopters are improving their main financial indicators compared to non-adopters. However, there is no support that this is achieved through an increase in sales. The improvements are the result of an increase in efficiency and cost savings. These are most likely achieved by other improvement claims due to ERP adoption, such as streamlined processes, better collaboration, increased productivity, etc., but testing these was outside the scope of this study. All in all it can be concluded that implementing ERP by firms in Pakistan has brought them most of the benefits ERP vendors claim. The fact that most of the positive effects already start during implementation and remain in the three years after may be due to the fact that Pakistani firms benefitted from the ERP implementation learning curve in other areas of the world. 


\section{Limitations}

This research has some limitations. First of all, it is assumed that the financial data published by the Pakistan Stock Exchange are reliable and meet accounting standards. To the best of our knowledge there is no evidence that any of the firm data used were compromised after the sample period.

Furthermore, it was not possible to find a matching non-adopter that met all the criteria for each adopter, so allowances had to be made to match firms. And although statistical tests were used to identify outliers the incomplete matches may affect the results, which is especially true for ROS and COGS.

No distinction was made between early and late adopters, nor were the number of modules identified. As Ugrin, Morris, and Ott (2016) showed, late adopters have an advantage over early adopters.

Finally, many studies on ERP implementation consider other activities, such as also introducing supply chain management, formal control systems, knowledge management, in combination with adopting ERP. In this study these activities were not included.

\section{REFERENCES}

Acar, M. F., Tarim, M., Zaim, H., Zaim, S., \& Delen, D. (2017). Knowledge management and ERP: Complementary or contradictory? International Journal of Information Management, 37(6), 703-712. https://doi.org/10.1016/j.ijinfomgt.2017.05.007

Amid, A., Moalagh, M., \& Zare Ravasan, A. (2012). Identification and classification of ERP critical failure factors in Iranian industries. Information Systems, 37(3), 227-237. https://doi.org/10.1016/j.is.2011.10.010

Anderson, M., Banker, R. D., Menon, N. M., \& Romero, J. A. (2011). Implementing enterprise resource planning systems: organizational performance and the duration of the implementation. Information Technology \& Management, 12(3), $197-212$. https://doi.org/10.1007/s10799-011-0102-9

Aral, S., \& Weill, P. (2007). IT assets, organizational capabilities, and firm performance: How resource allocations and organizational differences explain performance variation. Organization Science, 18(5), $763-780$. https://doi.org/10.1287/orsc.1070.0306

Badescu, M., \& Garcés-Ayerbe, C. (2009). The impact of information technologies on firm productivity: Empirical evidence from Spain. Technovation, 29(2), 122-129. https://doi.org/10.1016/j.technovation.2008.07.005

Balakrishnan, Linsmeier, \& Venkatachalam (1996) Financial Benefits from JIT Adoption - Effects of Customer Concentration and Cost Structure. The Accounting Review, 71(2), 183-205.

Banker, R.D., Bardhan, I. R., Chang, H. H., \& Lin, S. (2006). Plant information systems, manufacturing capabilities, and plant performance. MIS Quarterly, 30(2), 315-337. https://doi.org/10.2307/25148733

Barber, B. M., \& Lyon, J. D. (1996). Detecting abnormal operating performance: The empirical power and specification of test statistics. Journal of Financial Economics, 41(3), 359-399. https://doi.org/10.1016/0304-405X(96)84701-5

Beheshti, H. M., \& Beheshti, C. M. (2010). Improving productivity and firm performance with enterprise resource planning, Enterprise Information Systems, 4(4), 445-472. https://doi.org/10.1080/17517575.2010.511276

Bharadwaj, A. S. (2000). A resource-based perspective on information technology capability and firm performance: An empirical investigation. MIS Quarterly, 24(1), 169-196. https://doi.org/10.2307/3250983

De Andres, J., Lorca, P., \& Labra, E. J. (2012). The effects of ERP implementations on the profitability of big firms: the case of Spain. International Journal of Technology Management, 59(1-2), 22-44. https://doi.org/10.1504/IJTM.2012.047254

Dedrick, J., Gurbaxani, V., \& Kraemer, K. L. (2003). Information technology and economic performance: A critical review of the empirical evidence. ACM Computing Surveys, 35(1), 1-28. https://doi.org/10.1145/641865.641866

Devaraj, S., Krajewski, L., \& Wei, J. C. (2007). Impact of eBusiness technologies on operational performance: The role of production information integration in the supply chain. Journal of Operations Management, 25(6), $1199-1216$. https://doi.org/10.1016/j.jom.2007.01.002

Etezady, N. (2008). The Impact of ERP Investments on Organizational Performance (Doctoral dissertation). Nova Southeastern University. Retrieved from NSUWorks, Graduate School of Computer and Information Sciences.

Galy, E., \& Sauceda, M. J. (2014) Post-implementation practices of ERP systems and their relationship to financial performance. Information \& Management, 51, 310-319. https://doi.org/10.1016/j.im.2014.02.002

Gupta, S., Kumar, S, Singh, S.K., Foropon, C., \& Chandra, C. (2018) Role of cloud ERP on the performance of an organization. The International Journal of Logistics Management, 29(2), 659-675. https://doi.org/10.1108/IJLM-07-2017-0192

Hendricks, K. B., Singhal, V. R., \& Stratman, J. K. (2007). The impact of enterprise systems on corporate performance: A study of ERP, SCM, and CRM system implementations. Journal of Operations Management, $25(1), \quad 65-82$. https://doi.org/10.1016/j.jom.2006.02.002

Hitt, L. M., \& Brynjolfsson, E. (1996). Productivity, Business Profitability, and Consumer Surplus: Three Different Measures of Information Technology Value. MIS Quarterly, 20(2), 121-142. https://doi.org/10.2307/249475

Hitt, L. M., Wu, D. J., \& Zhou, X. G. (2002). Investment in Enterprise Resource Planning: Business impact and productivity measures. Journal of Management Information Systems, 19(1), 71-98. https://doi.org/10.1080/07421222.2002.11045716 
Hunton, J. E., Lippincott, B., \& Reck, J. L. (2003). Enterprise resource planning systems: comparing firm performance of adopters and non-adopters. International Journal of Accounting Information Systems, 4(3), 165-184. https://doi.org/10.1016/S14670895(03)00008-3

Johnson, H. T. (1978) Management Accounting in an Early Multidivisional Organization: General Motors in the1920s. The Business History Review, 52(4), 490-517. https://doi.org/10.2307/3113416

Kallunki, J.-P., Laitinen, E. K., \& Silvola, H. (2011). Impact of enterprise resource planning systems on management control systems and firm performance. International Journal of Accounting Information Systems, 12(1), $20-39$. https://doi.org/10.1016/j.accinf.2010.02.001

Kharuddin, S., Foong, S-Y \& Senik, R. (2015). Effects of decision rationality on ERP adoption extensiveness and organizational performance. Journal of Enterprise Information Management, 28(5), 658-679. https://doi.org/10.1108/JEIM-02-2014-0018

Kocaaga, A. S., Ervural, B. C., Demirel, O. F., \& Zaim, S. (2019). Analysis of the Relationship Between Enterprise Resource Planning Implementation and Firm Performance: Evidence from Turkish SMEs. Paper presented at the Proceedings of the International Symposium for Production Research 2018, Cham. https://doi.org/10.1007/978-3-319-92267-6_58

Kouki, A. (2015). Joint impact of ERP systems and non-financial performance indicators on corporate financial performance: Evidence from French listed companies. Management Science Letters, 5(1), 1-10. https://doi.org/10.5267/j.msl.2014.12.004

Liu, L, Miao, R., \& Li, C. (2008). The impacts of enterprise resource planning systems on firm performance: An empirical analysis of Chinese chemical firms. School of Economics and Management, Beihang University, Beijing 100083, P.R. China. https://doi.org/10.1007/978-0-387-75902-9_64

Liu, T. K., \& Lu, W. C. (2011). Information technology and total factor productivity. African Journal of Business Management, 5(14), 5895-5899. https://doi.org/10.5897/AJBM11.188

Lunardi, G. L., Becker, J. L., Maçada, A. C. G., \& Dolci, P. C. (2014). The impact of adopting IT governance on financial performance: An empirical analysis among Brazilian firms. International Journal of Accounting Information Systems, 15(1), 66-81. https://doi.org/10.1016/j.accinf.2013.02.001

Mabert, V. A., Soni, A., \& Venkataramanan, M. A. (2003). The impact of organization size on enterprise resource planning (ERP) implementations in the US manufacturing sector. Omega, 31(3), 235-246. https://doi.org/10.1016/S0305-0483(03)00022-7

Madapusi, A., \& D'Souza, D. (2012). The influence of ERP system implementation on the operational performance of an organization. International Journal of Information Management, 32(1), 24-34. https://doi.org/10.1016/j.ijinfomgt.2011.06.004

Maguire, S., Ojiako, U., \& Said, A. (2010). ERP implementation in Omantel: a case study. Industrial Management \& Data Systems, 110(1-2), 78-92. https://doi.org/10.1108/02635571011008416

Melville, N., Kraemer, K., \& Gurbaxani, V. (2004). Review: Information technology and organizational performance: An integrative model of IT business value. MIS Quarterly, 28(2), 283-322. https://doi.org/10.2307/25148636

Mithas, S, Tafti, A., Bardhan, I., \& Goh, J. M. (2012). Information technology and firm profitability: Mechanisms and empirical evidence. MIS Quarterly, 36(1), 205-224. https://doi.org/10.2307/41410414

Myers, S. C., \& Majluf, N. S. (1984). Corporate financing and investment decisions when firms have information that investors do not have. Journal of Financial Economics, 13(2), 187-221. https://doi.org/10.1016/0304-405X(84)90023-0

Nicolaou, A. I., \& Bajor, L. H. (2004). ERP Systems Implementation and Firm Performance. The Review of Business Information Systems, 8(1), 53-59. https://doi.org/10.19030/rbis.v8i1.4504

Nicoloau, A. I. (2004) Firm Performance Effects in Relation to the Implementation and Use of ERP Systems. Journal of Information Systems, 18(2), 79-105. https://doi.org/10.2308/jis.2004.18.2.79

Parto, A., Sofian, S., \& Saat, M. M. (2016). The impact of enterprise resource planning on financial performance in a developing country. International Review of Management and Business Research, 5(1), 176-187.

Poston, R., \& Grabski, S. (2001). Financial impacts of enterprise resource planning implementations. International Journal of Accounting Information Systems, 2(4), 271-294. https://doi.org/10.1016/S1467-0895(01)00024-0

Scott, J. E., \& Vessey, I. (2002). Managing Risks in Enterprise Systems Implementations. Communications of the ACM, 45(4), 74-81. https://doi.org/10.1145/505248.505249

Segars A. H., \& Chatterjee, D. (August 23, 2010). Diets That Don't Work: Where Enterprise Resource Planning Goes Wrong. Wall Street Journal.

Shang, S., \& Seddon, P. B. (2002). Assessing and managing the benefits of enterprise systems: the business manager's perspective. Information Systems Journal, 12(4), 271-299. https://doi.org/10.1046/j.1365-2575.2002.00132.x

Stratman, J. K. (2001). Information integration for supply chain management: an empirical investigation of ERP systems in manufacturing (Unpublished Ph.D. Dissertation) University of North Carolina, Chapel Hill, NC.

Tian, F., \& Xu, S. X. (2015a). How do Enterprise Resource Planning Systems Affect Firm Risk? Post-implementation Impact. MIS Quarterly, 39(1), 39-60. https://doi.org/10.25300/MISQ/2015/39.1.03

Ugrin, J. C., Morris, J. J., \& Ott, R. L. (2016) A Study of How Underperforming Firms Follow Industry Leaders When Adopting ERP Systems and the Economic Effects of Their Adoption Decisions. Communications of the AIS, 39, 52-72. https://doi.org/10.17705/1CAIS.03904 
Velcu, O. (2007). Exploring the effects of ERP systems on organizational performance: evidence from Finnish companies. Industrial Management \& Data Systems, 107(9), 1316-1334. https://doi.org/10.1108/02635570710833983

Whitaker, J., Mithas, S., \& Krishnan, M. S. (2010). Organizational Learning and Capabilities for Onshore and Offshore Business Process Outsourcing. Journal of Management Information Systems, 27(3), 11-42. https://doi.org/10.2753/MIS0742-12222270302

Wieder, B., Booth, P., Matolcsy, Z. P., \& Ossimitz, M.-L. (2006) The impact of ERP systems on firm and business process performance. Journal of Enterprise Information Management, 19(1), 13-29. https://doi.org/10.1108/17410390610636850

Zhang, H., \& Zheng, H. (2019). An Empirical Study on the Impact of ERP Implementation on the Performance of Listed Companies. Journal of Physics: Conference Series, 1213, 052103. https://doi.org/10.1088/1742-6596/1213/5/052103 


\section{ANNEX}

\section{Overview of Empirical Studies on ERP Adoption Effects}

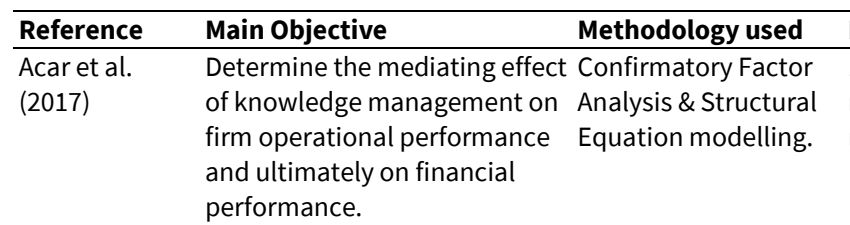

De Andrés et Examine the effects of ERP

al. (2012)

\section{implementations on firm} performance in big Spanish firms.

\begin{tabular}{|c|c|c|}
\hline $\begin{array}{l}\text { Galy \& } \\
\text { Sauceda } \\
(2014)\end{array}$ & $\begin{array}{l}\text { Empirically investigate a } \\
\text { cause-and-effect relationship } \\
\text { post-ERP implementation of } \\
\text { managerial actions and } \\
\text { financial performance. }\end{array}$ & Forward regression. \\
\hline $\begin{array}{l}\text { Gupta et al. } \\
(2018)\end{array}$ & $\begin{array}{l}\text { Empirically test the role of } \\
\text { cloud-based ERP services on } \\
\text { the supply chain and } \\
\text { organizational performance of } \\
\text { an organization. }\end{array}$ & $\begin{array}{l}\text { Confirmatory Factor } \\
\text { Analysis \& Partial } \\
\text { Least Square based } \\
\text { on SEM }\end{array}$ \\
\hline
\end{tabular}

\begin{tabular}{ll} 
Data used & Main findings \\
\hline 163 questionnaire & Results showed no significant positive direct
\end{tabular}

163 questionnaire Results showed no significant positive direct responses from Turkish effect of ERP on operational performance, but manufacturing firms. through knowledge management and thus operational performance ERP has a positive effect on financial performance (profit, revenue, $\mathrm{ROI})$.

Regression analysis to Survey with $72 \quad$ The ROA of adopters is significantly lower than
compare the responses of that of non-adopters in the three years after performance of companies that adoption. No significant effect on ROI or TAT, adopting and non- implemented between and a positive effect on sales in the first year 1989 and $2006 . \quad$ after adoption. 55 companies that ERP implementation in combination with adopted between 1993 applying various managerial techniques have a and $2001 . \quad$ significant positive effect on financial variables like Net Sales, ROA, ROI, etc.

Data from $154 \quad$ Cloud-based ERP services have a positive respondents to survey. impact on the supply chain and marketing performance, but not on financial performance. Overall Cloud ERP has a positive effect on supply chain performance through supply base complexity.

Hendricks et Analyzing the effect of Wilcoxon signed-rank 186 announcements of Although not uniformly, ERP adopters show an al. (2007) investments in ERP on a firm's test and the binomial ERP implementations. improvement in ROA. 58\% of the sample firms long-term stock price sign test using oneperformance and profitability tailed tests. Data for 2 year experienced a significant positive abnormal implementation and 3 change in ROA. Some evidence of positive year post.

abnormal changes in ROS, but the results are not as strong as for ROA. Firms do not experience a statistically significant increase in stock returns.

\begin{tabular}{|c|c|c|c|}
\hline $\begin{array}{l}\text { Hitt et al. } \\
(2002)\end{array}$ & $\begin{array}{l}\text { Systematically study the } \\
\text { productivity and business } \\
\text { performance effects of ERP } \\
\text { (SAP R/3 system) }\end{array}$ & Regression analysis. & $\begin{array}{l}\text { Data for } 24,037 \\
\text { companies among } \\
\text { which 4,069 adopters } \\
\text { between } 1986-1998 .\end{array}$ \\
\hline
\end{tabular}

\begin{tabular}{|c|c|c|c|c|}
\hline $\begin{array}{l}\text { Hunton et al. } \\
(2003)\end{array}$ & $\begin{array}{l}\text { Test whether the performance } \\
\text { of non-adopters declines } \\
\text { compared to ERP adopters in a } \\
\text { competitive market. }\end{array}$ & Regression analysis. & $\begin{array}{l}\text { Data of } 63 \text { adopters \& } \\
63 \text { non-adopters for } 3 \\
\text { year before, } 1 \text { year } \\
\text { during \& } 3 \text { year after } \\
\text { adoption. }\end{array}$ & $\begin{array}{l}\text { Adopters show a significant improvement of } \\
\text { ROA, ROI \& TAT compared to non-adopters. No } \\
\text { significant improvement for ROS was found. } \\
\text { No significant difference occurred between } \\
\text { pre- and post-performance for adopters. }\end{array}$ \\
\hline $\begin{array}{l}\text { Kallunki et al. } \\
(2011)\end{array}$ & $\begin{array}{l}\text { Explore the effects of ERP } \\
\text { adoption on the non-financial } \\
\text { and financial performance of } \\
\text { the firm, and whether formal } \\
\text { and informal management } \\
\text { control systems mediate these } \\
\text { effects. }\end{array}$ & Partial Least Squares. & $\begin{array}{l}\text { Survey data from } 70 \\
\text { Finnish business units } \\
\text { in } 2007 \text {. }\end{array}$ & $\begin{array}{l}\text { ERP systems are positively related the use of } \\
\text { formal and informal controls. ERP has a } \\
\text { significant effect on financial performance } \\
\text { (including ROA, ROI COGS, SG) only through } \\
\text { formal controls. }\end{array}$ \\
\hline $\begin{array}{l}\text { Kharuddin et } \\
\text { al. (2015) }\end{array}$ & $\begin{array}{l}\text { Exploring the relationship } \\
\text { between ERP adoption } \\
\text { extensiveness and financial } \\
\text { and non-financial } \\
\text { performance. }\end{array}$ & Regression analyses. & $\begin{array}{l}93 \text { responses from } \\
\text { unlisted Malaysian } \\
\text { manufacturing } \\
\text { companies that } \\
\text { adopted ERP. }\end{array}$ & $\begin{array}{l}\text { ERP adoption extensiveness, measured by the } \\
\text { extensiveness the modules implemented, has } \\
\text { significant positive effect on both financial and } \\
\text { non-financial performance. However, the latter } \\
\text { has a stronger relationship with ERP } \\
\text { extensiveness. }\end{array}$ \\
\hline $\begin{array}{l}\text { Kocaaga et al. } \\
(2019)\end{array}$ & $\begin{array}{l}\text { Analyze (subjective) measures } \\
\text { of performance (Critical } \\
\text { Success Factors) and their } \\
\text { impact on financial and non- } \\
\text { financial performance. }\end{array}$ & $\begin{array}{l}\text { Confirmatory Factor } \\
\text { Analysis \& Structural } \\
\text { Equation modeling. }\end{array}$ & $\begin{array}{l}215 \text { SMEs in the Turkish } \\
\text { textile sector. }\end{array}$ & $\begin{array}{l}\text { A statistically significant positive relationship } \\
\text { between ERP system performance and firm } \\
\text { performance. ERP system implementation } \\
\text { does not have a significant relationship with } \\
\text { firm performance. }\end{array}$ \\
\hline Kouki (2015) & $\begin{array}{l}\text { Analyzing the effect of ERP } \\
\text { adoption in combination with } \\
\text { non-financial performance } \\
\text { indicators. }\end{array}$ & $\begin{array}{l}\text { GLS multivariate } \\
\text { regression. }\end{array}$ & $\begin{array}{l}102 \text { French listed firms } \\
\text { for the period 2001-06. }\end{array}$ & $\begin{array}{l}\text { ERP adoption has a positive effect on ROA, but } \\
\text { this is much stronger when combined with } \\
\text { non-financial performance indicators. }\end{array}$ \\
\hline
\end{tabular}

Adopters perform better in terms of sales per employee, profit margins, ROA, TAT, ITO and accounts receivable turnover, but negative for ROE. Adopting firms have consistently better performance during than before or after, with the exception of accounts receivable turnover, which improves both during and after adoption.

Adopters show a significant improvement of ROA, ROI \& TAT compared to non-adopters. No significant improvement for ROS was found. No significant difference occurred between pre- and post-performance for adopters. ERP systems are positively related the use of significant effect on financial performance (including ROA, ROI COGS, SG) only through formal controls.

ERP adoption extensiveness, measured by the extensiveness the modules implemented, has significant positive effect on both financial and non-financial performance. However, the latter has a stronger relationship with ERP non-financial performance indicators. 


\begin{tabular}{|c|c|c|c|c|}
\hline Liu et al. (2008) & $\begin{array}{l}\text { Investigating the effects of ERP } \\
\text { adoption on firm performance } \\
\text { of Chinese firms using } \\
\text { objective financial data. }\end{array}$ & $\begin{array}{l}\text { t-test for hypotheses } \\
\text { and Kolmogorov- } \\
\text { Smirnov to test } \\
\text { whether the data are } \\
\text { normally distributed. }\end{array}$ & $\begin{array}{l}\text { Compare } 50 \text { Chinese } \\
\text { adopters and non- } \\
\text { adopters in the } \\
\text { chemical industry } \\
\text { during and after } \\
\text { implementation. }\end{array}$ & $\begin{array}{l}\text { No significant improvements during the } \\
\text { implementation period and the three-year } \\
\text { post-implementation period. Effect on ROA } \\
\text { significantly negative and on COGS } \\
\text { significantly positive in the first year after } \\
\text { adoption. Inconclusive results for ROS. }\end{array}$ \\
\hline $\begin{array}{l}\text { Nicolaou } \\
(2004)\end{array}$ & $\begin{array}{l}\text { Test the effects of ERP } \\
\text { implementation by comparing } \\
\text { matching adopters and non- } \\
\text { adopters, while controlling for } \\
\text { implementation } \\
\text { characteristics. }\end{array}$ & Regression analysis. & $\begin{array}{l}\text { Data for } 247 \text { firms of } \\
\text { adopters and matching } \\
\text { non-adopters. Data for } \\
3 \text { years pre-adoption, } 1 \\
\text { year adoption and } 4 \\
\text { year post-adoption, } \\
\text { covering 1990-98. }\end{array}$ & $\begin{array}{l}\text { ROA is significantly worse during and year one } \\
\text { after adoption, but improves in years } 2 \text { and } 4 . \\
\text { ROS deteriorates during adoption and } \\
\text { improves in years } 3 \text { and } 4 \text {. COGS improves in } \\
\text { year } 4 .\end{array}$ \\
\hline $\begin{array}{l}\text { Nicolaou \& } \\
\text { Bajor (2004) }\end{array}$ & $\begin{array}{l}\text { Test the effcts of ERP } \\
\text { implementation by comparing } \\
\text { adopters and non-adopters. }\end{array}$ & $\begin{array}{l}\text { t-test and Wilcoxon's } \\
\text { Z statistic. }\end{array}$ & $\begin{array}{l}213 \text { firm observarions } \\
\text { for } 3 \text { years pre- } \\
\text { adoption, adoption and } \\
2 \text { year post adoption. }\end{array}$ & $\begin{array}{l}\text { No significant differences for the averages over } \\
3 \text { years prior to adoption of ROA, ROS, ITO and } \\
\text { COGS between adopters and non-adopters. } \\
\text { Significant improvements for the averages } \\
\text { over } 2 \text { years post implementation for ROS and } \\
\text { COGS, but not for ROA and ITO. }\end{array}$ \\
\hline $\begin{array}{l}\text { Parto et al. } \\
\text { (2016) }\end{array}$ & $\begin{array}{l}\text { Explore the impact of ERP } \\
\text { implementation on the } \\
\text { financial performance of } \\
\text { Iranian manufacturing firms. }\end{array}$ & $\begin{array}{l}\text { Structural equation } \\
\text { model \& Partial Least } \\
\text { Squares \& } \\
\text { Bootstrapping. }\end{array}$ & $\begin{array}{l}302 \text { questionnaires } \\
\text { were collected from } 43 \\
\text { out of } 79 \\
\text { manufacturing } \\
\text { companies. }\end{array}$ & $\begin{array}{l}\text { Financial performance (ROA, ROI) improves } \\
\text { after implementation of individual modules as } \\
\text { well as an entire ERP system. }\end{array}$ \\
\hline $\begin{array}{l}\text { Poston \& } \\
\text { Grabski (2001) }\end{array}$ & $\begin{array}{l}\text { Analyze empirically the } \\
\text { potential contribution of ERP } \\
\text { to firm performance. }\end{array}$ & Pairwise sample t-test & $\begin{array}{l}50 \text { companies } \\
\text { implementing ERP } \\
\text { between } 1993-1997\end{array}$ & $\begin{array}{l}\text { No significant improvement in residual income } \\
\text { or the ratio of selling, general, and } \\
\text { administrative expenses. A significant } \\
\text { improvement in firm performance from a } \\
\text { decrease in COGS third year after adoption. A } \\
\text { significant reduction in the ratio of employees } \\
\text { to revenues for each of the } 3 \text { years after } \\
\text { adoption. }\end{array}$ \\
\hline Velcu (2007) & $\begin{array}{l}\text { Investigate the relationship } \\
\text { between the quality of ERP } \\
\text { implementations and firm } \\
\text { profitability. }\end{array}$ & Mann-Whitney U test. & $\begin{array}{l}\text { Compare } 32 \text { successful } \\
\text { implementations with } \\
17 \text { less successful ones. }\end{array}$ & $\begin{array}{l}\text { No significant difference in ROA or ROI after } \\
\text { implementation between successful and less } \\
\text { successful adoptions. However, successful } \\
\text { adopters have significantly better TAT in the } \\
\text { first two years after implementation. }\end{array}$ \\
\hline $\begin{array}{l}\text { Wieder et al. } \\
(2006)\end{array}$ & $\begin{array}{l}\text { Impacts of ERP adoption on } \\
\text { organizational performance } \\
\text { and providing evidence of the } \\
\text { benefits of bundling ERP with } \\
\text { SCM systems. }\end{array}$ & $\begin{array}{l}\text { Mann-Whitney U test } \\
\text { and two-sample } \\
\text { Kolmogorov-Smirnov } \\
\text { test; Pearson, Kendall } \\
\text { and Spearman } \\
\text { correlation; trend } \\
\text { analysis. }\end{array}$ & $\begin{array}{l}\text { Survey responses in } \\
2001 \text { of } 49 \text { adopters and } \\
40 \text { non-adopters from } \\
\text { all sectors of the } \\
\text { economy. }\end{array}$ & $\begin{array}{l}\text { No performance (including ROI) differences } \\
\text { between adopters and non-adopters, not on } \\
\text { the supply chain level, nor at the firm level. } \\
\text { However, the longer the experience of } \\
\text { adopters, the higher their performance at the } \\
\text { firm level. }\end{array}$ \\
\hline $\begin{array}{l}\text { Zhang \& Zheng } \\
\text { (2019) }\end{array}$ & $\begin{array}{l}\text { Investigation of the impact of } \\
\text { ERP on operating efficiency } \\
\text { and firm performance. }\end{array}$ & $\begin{array}{l}\text { Paired sample t-test } \\
\text { to determine the pre } \\
\text { to post- } \\
\text { implementation } \\
\text { performance. }\end{array}$ & $\begin{array}{l}\text { Data for } 60 \text { Chinese } \\
\text { companies } 3 \text { year pre, } 1 \\
\text { year implementation, } 4 \\
\text { year post } \\
\text { implementation. }\end{array}$ & $\begin{array}{l}\text { Significant positive effect in the first two years } \\
\text { after implementation for ROS \& ITO, and in the } \\
\text { first year for ROA. }\end{array}$ \\
\hline
\end{tabular}

